\title{
Comparison of random regression models, traditional animal model and with the inclusion of molecular markers in the estimation of genetic parameters in Colombian Holstein cattle
}

\author{
Comparação entre modelos de regressão aleatória, \\ modelo animal tradicional e com a inclusão de \\ marcadores moleculares na estimativa de parâmetros \\ genéticos em bovinos da raça Holandesa Colombiana
}

\author{
Daniel Cardona-Cifuentes ${ }^{1 *}$; Albeiro López-Herrera ${ }^{2}$; Luis Gabriel González- \\ Herrera²; Mario Fernando Cerón-Muñoz ${ }^{3}$; José Julián Echeverri-Zuluaga ${ }^{2}$
}

\section{Highlights}

The MBLUP model led to greater estimates of genetic variance and greater heritability. Molecular markers had different effect on traits, milk yield was the most affected.

Random regression model presented lower heritability and less accurate genetic value.

\begin{abstract}
The use of molecular markers to identify desirable genes in animal production is known as marker-assisted selection. The traditional genetic evaluation model uses the BLUP methodology; when genetic markers are included in the evaluation model, the methodology is known as M-BLUP. In contrast, random regression models (RRM), unlike the models based on production at 305 days, consider factors that change for each animal from one test to another. The objective of this study was to compare variance components, genetic parameters and breeding values for milk production, protein percentage and somatic cell score in Colombian Holstein cattle using BLUP, M-BLUP and RRM. For the estimation of genetic parameters and values, 2003 lactations corresponding to 1417 cows in 55 herds were used, and effects of the order of delivery, herd, and contemporary group were included. The three traits presented greater heritability under the MBLUP model: 0.44 for protein percentage, 0.27 for milk production and 0.28 for somatic cell score. This was because the

1 Prof., Universidad Nacional Abierta y a Distancia CEAD Medellín, Escuela de Ciencias Agrícolas Pecuarias y del Medio Ambiente, Medellín, Antioquia, Colombia. E-mail: dcardonac@unal.edu.co

2 Profs., Universidad Nacional de Colombia sede Medellín, Facultad de Ciencias Agrarias, Departamento de Producción Animal, Grupo de Investigación BIOGEM, Medellín, Colombia. E-mail: alherrera@unal.edu.co; luggonzalezhe@unal.edu. co; jjecheve@unal.edu.co

3 Prof., Universidad de Antioquia, Facultad de Ciencias Agrarias, Grupo de Investigación GAMMA, Medellín, Colombia. E-mail: mario.ceron@udea.edu.co

* Author for correspondence
\end{abstract}

Received: July 29, 2020 - Approved: Feb. 04, 2021 
genetic variance was greater when M-BLUP was used, which allowed a greater accuracy of the breeding value estimation in the three traits. Therefore, the model that includes information on molecular markers is more suitable for genetic evaluation in Colombian Holstein cattle.

Key words: Dairy cattle. Animal genetics. Genetic markers. Animal breeding. Dairy production.

\section{Resumo}

O uso de marcadores moleculares para identificar genes desejáveis na produção animal é conhecido como seleção assistida por marcadores. O modelo tradicional de avaliação genética utiliza a metodologia BLUP, e quando os marcadores genéticos são incluídos no modelo de avaliação, a metodologia é conhecida como M-BLUP. Por outro lado, os modelos de regressão aleatória (RRM), ao contrário dos modelos baseados em produções a 305 dias, consideram fatores que mudam para cada indivíduo de um controle para outro. O objetivo deste estudo foi comparar componentes de variância, parâmetros e valores genéticos para produção de leite, percentagem de proteína e escore de células somáticas em gado holandês de Colômbia utilizando BLUP, M-BLUP e RRM. Para a estimativa de parâmetros e valores genéticos, foram utilizadas 2.003 lactações correspondentes a 1.417 vacas de 55 rebanhos e efeitos da ordem de parto, rebanho e grupo contemporâneo. Os três traços apresentaram maior hereditariedade no modelo MBLUP, 0,44 para percentagem de proteína, 0,27 para produção de leite e 0,28 para escore de células somáticas. Isso por causa da variância genética foi maior quando o M-BLUP foi utilizado, o que permitiu estimar maior precisão do valor genético nos três traços, portanto, o modelo que inclui informações sobre marcadores moleculares é mais adequado para avaliação genética em gado holandês colombiano.

Palavras-chave: Gado leiteiro. Genética animal. Marcadores genéticos. Melhoramento animal. Produção leiteira.

\section{Introduction}

In department of Antioquia, Colombia, where the Holstein breed is commonly used, the dairy industry has been well-developed. Because Colombia has a payment system for milk that is based on compositional quality, farmers need to maintain an optimum quantity and quality of milk production. Animal genetic improvement is an important tool for this process. However, due to the absence of traceability programs, databases for use in genetic evaluation are scarce and unreliable. Although important research advances have been made in estimating genetic parameters and breeding values, the methodology that best suits the scarce phenotypic and genealogical information available in the country has not yet been identified. For this reason, it is important to continue testing different genetic evaluation methodologies.

The first methodology considered is the traditional procedure for genetic evaluations, known as the animal model, where selection is based on genealogical and phenotypic information. This methodology uses the BLUP (best linear unbiased predictor) to calculate estimated breeding values (EBVs) for animals in the evaluation (Mrode, 2005). Additionally, there are two approaches for the genetic evaluation of milk production traits; one uses milk production per lactation of several deliveries, and the other analyzes measurements of milk production on the test day collected from a single lactation. In both cases, the different records are assumed to be repeated measures 
of the same trait. Test day measurements capture changes in the mean, covariance between records and permanent environment effects over the course of lactation, along with genetic correlations, which tend to decrease as the time between measurements increases. This issue is ignored by repeatability models but is properly considered by random regression models (RRMs) (Mrode, 2005).

This RRM can consider specific factors for each test day, such as the month or season in which the measurement is performed. In RRM, fixed regressions are used for all cows in the same subclass to describe the general shape of the lactation curve, and random regressions for each cow describe genetic deviations, allowing the production of a different genetic lactation curve for each cow (Jamrozik, Schaeffer, \& Dekkers, 1997). Genetic differences can be modeled by Legendre polynomials, which have been identified as the most suitable equations for modeling milk production (Strabel \& Jamrozik, 2006; Bignardi et al., 2011). Additionally, heterogeneous residual variance structures allow us to better model environmental effects (Dornelles et al., 2016). The advantages of RRM are the increase in genetic value reliability and their ability to be used in animal selection based on the test day with the highest heritability, reliability and correlation with production per lactation, allowing an evaluation of early lactation and accelerating the selection processes (Manoel et al., 2007).

The use of molecular markers to identify desirable genes in animal production is called marker-assisted selection (MAS). This process uses not only phenotypic and pedigree information but also information about variations in genes with effects on important quantitative traits. The advantage of MAS lies in the possibility of improving estimates of genetic parameters in sex-specific traits that have low heritability or are difficult to measure, and hence a great opportunity to reduce generational intervals (Meuwissen, Hayes, \& Goddard, 2013; Wakchaure et al., 2015). When molecular marker information is included in the model for genetic evaluation, the resulting estimate of breeding values using BLUP and MAS is called M-BLUP, which allows the calculation of the random effect of each marker and the polygenic effect of other genes not included in the model, resulting in the transformation of EBV into the molecular estimated breeding value (MEBV) (Hayes, 2007).

In this way, random regression models and marker-assisted selection represent two important strategies that could help increase the reliability of genetic parameters and breeding values in Colombian Holstein cattle populations, for which there is currently limited information. Therefore, the objective of this study was to compare the estimated variance components, genetic parameters, and breeding values for milk production (MP), protein percentage (PP) and somatic cell score (SCS), using random regression model, traditional animal model, and markerassisted selection model, to determine which model best describes the genetic parameters and therefore should be used in the genetic evaluation of these traits in Holstein cattle from Antioquia.

\section{Materials and Methods}

Phenotypic data were collected through dairy control programs developed by the BIOGEM research group of the Universidad Nacional de Colombia Medellín campus. These 
programs were developed between 2008 and 2015. During this process, 157 farms from the northern and eastern regions of Antioquia, Colombia, were visited at intervals of 30 to 60 days, and the daily production for each cow was measured with True test ${ }^{\circledR}$ proportional flux meters in herds with mechanical milking or bucket measurement in herds with manual milking. Additionally, milk samples were taken for protein percentage and somatic cell score analyses. Milk production per lactation was estimated according to the following equation (Barbosa, Cruz,Costa, \& Rodrigues, 1999):

$M P=\left(T_{1} * E_{1}\right)+\sum_{\mathrm{i}=2}^{\mathrm{n}} \llbracket\left(\left(T_{\mathrm{i}}+T_{\mathrm{i}-1} / 2\right) * E_{\mathrm{i}}\right)+\left(T_{\mathrm{n}} * \mathrm{E}_{\mathrm{n}} \rrbracket\right)$

where MP represents the milk production per lactation, T1 is the milk production in the first control, E1 is the interval between delivery and the first control, $\mathrm{n}$ represents the number of controls, $\mathrm{Ti}$ is the milk production per control ( $i=1,2,3 \ldots, n$ ), Ei is the interval between two consecutive controls, $\mathrm{Tn}$ is the milk production in the last control, and En is the interval between the last control and the end of lactation.
Protein percentage and somatic cell score were determined by using the MilkoScan $\mathrm{FT}^{120^{\circledR}}{ }^{\circledR}$, whose measurements are based on FTIR (Fourier transform infrared), a process accepted by the ICAR. Subsequently, the somatic cell score (SCS) was transformed into the somatic cell score (SCS) (Wiggans \& Shook, 1987):

$$
S C S=\log _{2}(R C S / 1000)+3
$$

From these data, those cows with as many phenotypic records as possible were genotyped, although not all individuals were typed for each gene under study. For this, blood samples were collected for DNA extraction using the salting-out method, and subsequently PCR-RFLP was used to evaluate ten polymorphisms of nine genes. These procedures were performed in the Animal Biotechnology Laboratory of Universidad Nacional de Colombia at Medellín. A total of 2,003 lactations corresponding to 1,417 cows in 55 herds were used, and a pedigree was constructed with 2,596 animals, of which 321 were bulls. Descriptive analysis of the traits is presented in Table 1.

\section{Table 1}

Descriptive analysis of milk production (MP), protein percentage (PP), and somatic cell score (SCS) in Holstein cattle from Antioquia

\begin{tabular}{|cccccc|}
\hline Variable & Lactations & Individuals & Mean & Standard deviation & Coefficient of variation \\
\hline MP (L) & 2003 & 1417 & 5443.92 & 1512.900 & $27.790 \%$ \\
\hline PP (\%) & 1663 & 1223 & 3.05 & 0.200 & $6.620 \%$ \\
\hline SCS & 1743 & 1267 & 4.39 & 1.280 & $29.230 \%$ \\
\hline
\end{tabular}


The SAS/STAT $^{\circledR} \quad$ (Copyright $^{\odot} \quad 2003$ SAS Institute Inc.) was used to develop linear models through the GLM procedure, which allowed the identification of the sources of variation that should be included in the genetic evaluation model: order of delivery, herd, and contemporary group (year and month of birth). Although different covariables were included for each trait in the analysis, lactation duration was included as a covariable in the model for milk production, while milk production and lactation duration were included in the mode for protein percentage and somatic cell score.

The estimation of EBV was carried out through the traditional procedure known as the animal model and using the BLUP methodology, based on the following scheme of mixed equations (Mrode, 2005).

$$
\left[\begin{array}{cc}
X^{\prime} X & X^{\prime} Z \\
Z^{\prime} X & Z^{\prime} Z+A^{-1} \alpha
\end{array}\right]\left[\begin{array}{l}
\hat{b} \\
\hat{a}
\end{array}\right]=\left[\begin{array}{c}
X^{\prime} y \\
Z^{\prime} y
\end{array}\right]
$$

where y represents the vector of phenotypic records (MP, PP or SCS), b is a vector for fixed effects, a represents the random effect of the animal, $X$ is a design matrix that connects records with fixed effects, and $Z$ is a design matrix that connects records with random effects of animals.

The effect of molecular markers was estimated using the M-BLUP model described by (Hayes, 2007), which includes a vector that correlates the effect of markers with phenotypic information.

$$
\left[\begin{array}{l}
\hat{\mu} \\
\hat{g} \\
\hat{u}
\end{array}\right]=\left[\begin{array}{ccc}
1_{n}{ }^{\prime} 1_{n} & 1_{n}{ }^{\prime} X & 1_{n}{ }^{\prime} Z \\
X^{\prime} 1_{n} & X^{\prime} X & X^{\prime} Z \\
Z^{\prime} 1_{n} & Z^{\prime} X & Z^{\prime} Z+A^{-1} \alpha
\end{array}\right]^{-1}\left[\begin{array}{c}
1_{n}{ }^{\prime} y \\
X^{\prime} y \\
Z^{\prime} y
\end{array}\right]
$$

In this case, $X$ is a design matrix that contains records for markers and fixed effects, $g$ is a vector for the effect of the molecular marker, $\mathbf{Z}$ is a design matrix that relates phenotypic records and polygenic effect, $u$ is a polygenic effect vector, and $e$ is the residual error. Through the above procedure, it is possible to estimate the MEBV using the following expression:

$$
y=\hat{u}+\sum_{i}^{p} X_{i} \widehat{g_{\imath}}
$$

where y represents the solution for molecular breeding values, $\mathrm{p}$ is the number of molecular markers, and $\mathrm{Xi}$ is the column of the design matrix that relates the markers to the animal, the effect of each marker and the polygenic effect of the other genes. To estimate covariance components, the maximum restricted likelihood method was used using MTDFREML (Multiple-Trait Derivative-Free Restricted Estimator Maximum Likelihood) software (Van Vleck \& Boldman, 1993).

From the previously reported lactations, it was possible to collect 14,154 records for 1,064 animals. Seeking adequate consistency for the RRM, data from those animals that had fewer than four records per lactation or that did not have a milk sample recorded in the first ninety days after calving were discarded. Additionally, samples from lactations of different calving orders were recorded for some animals; however, the number of repeated records was not large enough to achieve convergence in the repeatability models, so the first lactation registered was random for each animal. In the end, information on milk production was available on the sampling day for 733 individuals. Table 2 shows the number of observations obtained for each control the mean and standard deviation for milk production, protein percentage, and somatic cell score. 
Table 2

Range of days in milk (DIM), number of records (n), and mean and standard deviation (SD) for milk production (MP), protein percentage (PP) and somatic cell score (SCS) for ten test days in Holstein cattle from Antioquia

\begin{tabular}{|ccccccccccc|}
\hline \multirow{2}{*}{ Control } & DIM & \multicolumn{3}{c}{ MP (L) } & \multicolumn{3}{c}{ PP (\%) } & \multicolumn{3}{c|}{ SCS } \\
\cline { 3 - 10 } & & $\mathrm{n}$ & Mean & SD & $\mathrm{n}$ & Mean & SD & $\mathrm{n}$ & Mean & SD \\
\hline 1 & $5-30$ & 342 & 22.500 & 6.340 & 314 & 2.930 & 0.320 & 292 & 3.230 & 1.580 \\
\hline 2 & $31-60$ & 457 & 23.010 & 5.850 & 456 & 2.700 & 0.280 & 417 & 3.240 & 1.600 \\
\hline 3 & $61-90$ & 513 & 21.370 & 6.070 & 485 & 2.750 & 0.260 & 439 & 3.390 & 1.530 \\
\hline 4 & $91-120$ & 454 & 20.430 & 5.860 & 458 & 2.800 & 0.260 & 420 & 3.690 & 1.520 \\
\hline 5 & $121-150$ & 494 & 19.060 & 5.450 & 466 & 2.850 & 0.250 & 426 & 4.010 & 1.530 \\
\hline 6 & $151-180$ & 467 & 17.570 & 5.180 & 468 & 2.910 & 0.240 & 442 & 4.100 & 1.320 \\
\hline 7 & $181-210$ & 498 & 16.350 & 4.870 & 467 & 2.990 & 0.250 & 456 & 4.310 & 1.330 \\
\hline 8 & $211-240$ & 493 & 15.230 & 4.840 & 484 & 3.070 & 0.270 & 454 & 4.510 & 1.210 \\
\hline 9 & $241-270$ & 492 & 13.780 & 4.760 & 473 & 3.150 & 0.260 & 429 & 4.530 & 1.130 \\
\hline 10 & $270-305$ & 448 & 12.770 & 4.350 & 427 & 3.250 & 0.290 & 403 & 4.760 & 1.150 \\
\hline
\end{tabular}

Subsequently, genetic parameters and breeding values were estimated using an RRM, where the control day records for all three traits were analyzed with a model that used thirdand fourth-order Legendre polynomials for the additive and permanent environmental genetic effects, respectively, and a heterogeneous residual variance structure made up of twelve

$$
\left[\begin{array}{cc}
X^{\prime} R^{-1} X & X^{\prime} R^{-1} Q \\
Q^{\prime} R^{-1} X & Q^{\prime} R^{-1} Q+A^{-1} \otimes G \\
Z^{\prime} R^{-1} X & Z^{\prime} R^{-1} Q
\end{array}\right.
$$

Here, $y$ is the vector of control day observations, $b$ is the solution vector for the control day group effect and fixed regression coefficients for fixed effects of parity order, days in milk and contemporary group (test year, season and herd), $u$ is the vector of random regressions for additive genetics effects, pe is the vector of random regressions for permanent environment effects, $X$ is the classes for milk production and protein percentage and eleven classes for somatic cell score. Compared with the results of previous analyses, it was possible to establish that this structure was the one that best described the effects of interest. The RRM for the analysis of sampling day observations was as follows:

$$
\left.\begin{array}{c}
X^{\prime} R^{-1} Z \\
Q^{\prime} R^{-1} Z \\
Z^{\prime} R^{-1} Z+P
\end{array}\right]\left[\begin{array}{c}
\hat{b} \\
\hat{u} \\
\hat{p e}
\end{array}\right]=\left[\begin{array}{c}
X^{\prime} R^{-1} y \\
Q^{\prime} R^{-1} y \\
Z^{\prime} R^{-1} y
\end{array}\right]
$$

incidence matrix that relates data and fixed effects, $Q$ is the matrix that relates phenotypic observations and random effect of the animal, $\mathbf{Z}$ is the matrix that relates phenotypic observations and permanent environmental effects, e is the residual effect vector, $A$ is the kinship matrix between individuals, and $\square$ is the Kronecker product. Based on the above, it is assumed that:

$$
\operatorname{Var}(u)=A \otimes G ; \operatorname{Var}(p e)=I \otimes P ; \operatorname{Var}(e)=R
$$


where $\mathrm{I}$ is the identity matrix, $\mathrm{R}$ is the matrix containing the residual variance, and $G$ and $P$ are the covariance matrices between the random regression coefficients of additive genetics and the permanent environment, respectively. Finally, the (co)variance components were estimated via maximum restricted likelihood using Wombat software (Meyer, 2007).

For BLUP and MBLUP, for the three evaluated traits, the genetic value is determined as a single measure at the end of lactation. Meanwhile, the RRM, which makes use of test day measurements, allows the estimation of genetic values for each day in milk, so it was necessary to sum these daily genetic values to obtain a single genetic value for each trait at the end of a 305-day lactation to be able to compare the three models. This estimate is obtained from the product of solutions of random regression coefficients by animal and the polynomial value for each day. Solutions for the additive coefficients of random genetic regression of animal $\mathrm{j}$ are represented as follows, where a0, a1 and a2 represent the intercept and the linear and quadradic coefficients, respectively (Pereira et al., 2012).

$$
\widehat{a}^{\prime}=\left[\widehat{a_{0}} \widehat{a_{1}} \widehat{a_{2}}\right]
$$

The genetic value for animal $\mathrm{j}$ on day $\mathrm{t}$ is given by:

$$
E B V_{j t}=C_{t} \widehat{a}^{\prime}
$$

where $\mathrm{Ct}$ is the vector of covariables of Legendre polynomials on day t. The estimated genetic values for milk production, protein percentage or somatic cells at 305 days (EBV305) would then be given by the sum of the genetic values for the 305 days of lactation of each animal, according to the equation.

$$
E B V_{305}=\sum_{t=5}^{305} E B V_{j t}
$$

The estimates of genetic variance $\left(\delta_{a(305)}^{2}\right)$ and permanent environment variance $\left(\delta_{p e(305)}^{2}\right)$ for milk production, average protein percentage and somatic cell score at 305 days were estimated from the multiplication of the covariance matrices between the coefficients of regression for the additive genetic $\left(\Lambda_{a}\right)$ and permanent environment $\left(\Lambda_{p e}\right)$ random effects and the vectors that contained the specific covariables for the traits $(\mathrm{F})$, as described below:

$$
\begin{gathered}
\delta_{a(305)}^{2}=F^{\prime} \Lambda_{a} F \\
\delta_{p e(305)}^{2}=F^{\prime} \Lambda_{p e} F
\end{gathered}
$$

The residual variance $\left(\delta_{e_{(305)}^{2}}^{2}\right)$ estimates for each trait were calculated as the sum of the products of the twelve residual variance classes ( $V e_{j}$ with $\mathrm{j}$ equal to 1 to 12 ) and the number of days in milk (DIM) in each group (González-Herrera, 2013).

$$
\delta_{e(305)}^{2}=\sum V e_{j}(D I M)
$$

From the above, the heritability $\left(\mathrm{h}_{305 d}^{2}\right)$ for MP, PP, and SCS using RRMs was estimated according to Jakobsen et al. (2002).

$$
h_{305 d}^{2}=\frac{\delta_{a(305)}^{2}}{\delta_{a(305)}^{2}+\delta_{p e(305)}^{2}+\delta_{e}^{2}}
$$

Later, through Pearson correlations, it was determined which of the three random regression coefficients allowed us to model the magnitude of the genetic value at 305 days to estimate the reliability of the genetic value through the reliability for this coefficient.

To identify significant differences between the average accuracy of the breeding value, an analysis of variance was performed, including the effect of the methodology used through the SAS/STAT ${ }^{\circledR}$ and its GLM procedure. Finally, ranking correlations were 
used to measure the degree of association between the ranking of individuals selected by the models under analysis.

\section{Results and Discussion}

For all three traits, the RRM estimated lower heritability, while the M-BLUP model presented the highest values for this parameter. PP was the trait with the highest heritability in the three models, followed by SCS, and MP presented the lowest values (Table 3). The heritability values for MP estimated under the BLUP model were close to what was found in the literature, which indicates that this trait usually presents a medium heritability. In
Colombia, values between 0.16 and 0.24 have been reported for this trait (Solarte Portilla, \& Zambrano Burbano, 2012; Zambrano, Liu, Reinhardt, Reents, 2014; Rincón, Zambrano, \& Echeverri, 2015); similarly, several authors in different countries report values between 0.18 and 0.25 (Zink, Lassen, \& Štipkova, 2012; Zhao et al., 2015). On the other hand, the heritability for MP at 305 estimated using a random regression model $(0.15)$ was lower than that estimated by other authors, who reported values between 0.3 and 0.42 for the first and second lactations (Jakobsen et al., 2002; HaileMariam, Bowman, \& Goddard, 2003; Yamazaki et al., 2013).

\section{Table 3}

Variance components and heritability for milk production, protein percentage, and somatic cell score in Holstein cattle from Antioquia estimated through BLUP, M-BLUP and RRM

\begin{tabular}{cccccccccc} 
Variance & \multicolumn{3}{c}{ Milk production (L) } & \multicolumn{3}{c}{ Protein percentage (\%) } & \multicolumn{3}{c}{ Somatic cell score } \\
\cline { 2 - 9 } Component & BLUP & M-BLUP & RRM & BLUP & M-BLUP & RRM & BLUP & M-BLUP & RRM \\
\hline h2 & $0.260 \pm 0.00$ & $0.270 \pm 0.00$ & 0.150 & $0.400 \pm 0.04$ & $0.44 \pm 0.04$ & 0.290 & $0.270 \pm 0.04$ & $0.280 \pm 0.04$ & 0.220 \\
PV & 1574851 & 1574850 & 718940 & 0.031 & 0.031 & 0.049 & 1.286 & 1.287 & 1.506 \\
GAV & 407279 & 407279 & 106853 & 0.012 & 0.013 & 0.014 & 0.349 & 0.361 & 0.337 \\
EV & 1167872 & 1167860 & 612087 & 0.019 & 0.017 & 0.036 & 0.938 & 0.926 & 1.169 \\
\hline
\end{tabular}

PV: Phenotypic variance, GAV: genetic additive variance, EV: environmental variance.

PP is reported by several authors to be one of the traits with the highest heritability, with values commonly close to or greater than 0.3 (Zambrano et al., 2014; Rincón et al., 2015) or even reaching values between 0.47 and 0.65 (Makgahlela et al., 2013; Zhao et al., 2015; Gebreyesus et al., 2016), and this trait is less affected by environmental effects than milk production is (Lipkin, Bagnato, \& Soller, 2008a). The heritability found for PP with the random regression model was 0.29, surpassing that reported by other authors (Khanzadeh, Hossein, \& Naserani, 2013); however, it is important to highlight that few reports on heritability of protein percentage use this methodology; random regression has typically been used to model protein content rather than protein percentage (De Roos, Harbers, \& De Jong, 2004; Caccamo et al., 2008; Múnera, Herrera, Gonzáles, Henao, \& Cerón, 2014). 
It is generally accepted that SCS is a trait of low heritability (Zambrano et al., 2014; Costa, Santos, Cobuci, Thompson, \& Carvalheira, 2015); however, in this study, values were high in all models $(0.27,0.28$ and 0.22 for BLUP, M- BLUP and RRM, respectively) and close to those reported by some other authors (Kheirabadi \& Alijani, 2014). It is also noteworthy that previously published values are closer to the random regression results in this study, with reports ranging from 0.18 to 0.22 (Liu, Reinhardt, \& Reents, 2000; Mrode \& Swanson, 2004).

In the present study, the heritability estimates at 305 using RRM were lower than those estimated using the traditional animal model and the model that included information on molecular markers. This decrease is mainly explained by the increase in the environmental variance when RRM was used. This is contrary to the literature reports, where it has been said that control day models expect that additive genetic variance for the total production at 305 days is relatively high, since the residual and permanent environment variations are diluted, this results in higher heritability for production per lactation compared to control day production and less heritability for total production in repeatability models (De Roos et al., 2004).
The methodology used in the BLUP and M-BLUP models uses total or average lactation records per lactation for the traits under analysis, where genetic correlations and permanent environment equal to one are assumed for all the controls measurements that make up the registry, collecting the accumulated variation of both sources in a single value. For this reason, when linear models are used for lactation, the variation in the permanent environment can be diluted between environmental variance and genetic additive variance, and high values of the latter generate high values of heritability. On the other hand, RRM allows us to measure changes in the additive, residual, and permanent environmental genetic effects along the path in which the characteristic is expressed. When RRM was used in the present population, these effects of the temporary and permanent environment were of great importance, which led to decreases in the magnitude of genetic variation and heritability in comparison with BLUP and M-BLUP. Table 4 presents the permanent environmental and temporary environmental components obtained under the RRM.

Table 4

Components of environmental variance using random regression models for milk production, protein percentage, and somatic cell score in Holstein cattle from Antioquia 
The heritability values estimated by the M-BLUP model were higher than the BLUP and RRM estimates for the three traits due to an increase in genetic variance when the model that included molecular markers was used. When this technique was used, the estimation of heritability for MP was close to that from some reports that have used MAS, i.e., between 0.25 and 0.3; likewise, the value found for protein percentage may be even higher than those reported in this study (Guillaume, Fritz, Boichard, \& Druet, 2008a; Lipkin et al., 2008a; Lipkin, Tal-Stein, Friedmann, \& Soller, 2008b). The heritability for SCS was not substantially affected by the implementation of MBLUP, with very little change in the additive genetic variance, and the value was far from that reported by Ron et al. (2004), who used a marker-assisted selection model and reported a low heritability for this trait. One of the factors that determines genetic progress is the genetic standard deviation as a reflection of genetic variation (Schefers \& Weigel, 2012); therefore, evaluation methodologies that allow a better and greater estimation of this component will lead to higher heritability and promote genetic progress.

The different markers under study affected the genetic variance of each trait in a differentiated manner, so they represented different proportions within the genetic variance, with MP being the trait in which they had the greatest participation (Table 5). In the case of this trait, polymorphisms corresponding to the genes BGH, FSHR, IGF2, KC, LEP, PRL and PPARGC1 (first polymorphism) had a greater effect, while in the case of protein percentage, $\mathrm{KC}$ and $\mathrm{PRL}$ accounted for a greater proportion of the variation. In contrast, markers made little contribution to the genetic variance of somatic cell score, where polymorphisms of the LEP and PRL genes showed greater importance.

\section{Table 5}

Genetic variance explained by ten molecular markers for milk production (MP), protein percentage (PP), and somatic cell score (SCS) traits in Holstein cattle from Antioquia

\begin{tabular}{|cccc|}
\hline Gene & MP & PP & SCS \\
\hline BGH & 5575.770 & $1.000 \mathrm{E}-08$ & $1.320 \mathrm{E}-08$ \\
\hline FSHR & 2.377 & $1.000 \mathrm{E}-08$ & $1.320 \mathrm{E}-08$ \\
\hline IGF2 & 7653.890 & $1.029 \mathrm{E}-08$ & $1.160 \mathrm{E}-07$ \\
\hline INHA & 0.013 & $1.002 \mathrm{E}-08$ & $1.440 \mathrm{E}-08$ \\
\hline KC & 37324.170 & $1.057 \mathrm{E}-03$ & $1.340 \mathrm{E}-08$ \\
\hline LEP & 12063.910 & $1.000 \mathrm{E}-08$ & $2.470 \mathrm{E}-03$ \\
\hline POU1f1 & 0.014 & $1.006 \mathrm{E}-08$ & $1.410 \mathrm{E}-08$ \\
\hline PRL & 3174.170 & $3.557 \mathrm{E}-04$ & $8.460 \mathrm{E}-03$ \\
\hline PPARGC1 (1) & 6913.890 & $1.015 \mathrm{E}-08$ & $1.190 \mathrm{E}-08$ \\
\hline PPARGC1 (2) & 0.019 & $1.070 \mathrm{E}-08$ & $1.190 \mathrm{E}-08$ \\
\hline Total MV & 75082.840 & 0.001 & 0.011 \\
\hline MVIGAV & 0.180 & 0.110 & 0.030 \\
\hline
\end{tabular}

MV: marker variance, MVIGAV: ratio of marker variance to total additive genetic variance. 
In Table 6, it is possible to observe the effect of alleles of different SNPs on each evaluated trait; some genotypes led to an increase in the breeding value of the animals, whereas others generated decreases. The breeding value for MP was negatively affected by the (-) alleles of $b G H$; the $B$ allele of $P R L$; the $T$ allele of IGF2a; the $G$ allele of INHA; the $B$ allele of KC; the T allele of FSHR; and the $\mathrm{C}$ and
T alleles of the PPARGC1 gene. The breeding value for PP was negatively affected by the (-) alleles of $b G H$, the $B$ allele of $P R L$, the T allele of FSHR, and the $\mathrm{C}$ and $\mathrm{T}$ alleles of the PPARGC1 gene. On the other hand, SCS was negatively affected by (-) polymorphisms of $b G H$, the $B$ allele of $P R L$, the $G$ allele of INHA, the $T$ allele of FSHR, and the T allele of the second polymorphism of the PPARGC1 gene.

\section{Table 6}

Allelic substitution effects for ten polymorphisms on the molecular breeding value for milk production (MP), protein percentage (PP), and somatic cell score (SCS) in Holstein cattle from Antioquia

\begin{tabular}{|c|c|c|c|c|}
\hline \multirow{2}{*}{ Gene } & \multirow{2}{*}{ Substitution } & \multicolumn{3}{|c|}{ Trait } \\
\hline & & MP & $\mathrm{PP}$ & SCS \\
\hline $\mathrm{BGH}$ & $\begin{array}{c}+/- \\
\text { c. } 2141\end{array}$ & -131.099 & $-0,001$ & -0.046 \\
\hline PRL & $\begin{array}{c}\text { A/B } \\
\text { c. } 7544\end{array}$ & -113.510 & -0.0050 & -0.128 \\
\hline IGF2a & $\begin{array}{c}\text { C/T } \\
\text { c. } 292\end{array}$ & -69.440 & 0.011 & 0.024 \\
\hline POU1F1 & $\begin{array}{c}\text { A/B } \\
\text { c. } 207\end{array}$ & 20.800 & 0.008 & 0.054 \\
\hline INHA & $\begin{array}{c}\text { A/G } \\
\text { c. } 192\end{array}$ & -68.320 & 0.016 & -0.054 \\
\hline LEP & $\begin{array}{c}A / C \\
\text { c. } 1180\end{array}$ & 45.990 & 0.001 & 0.183 \\
\hline $\mathrm{KC}$ & $\begin{array}{c}\text { A/B } \\
\text { c. } 380\end{array}$ & -144.530 & 0.032 & 0.014 \\
\hline PPARGC1 (SNP1) & $\begin{array}{c}A / C \\
\text { c. } 1892\end{array}$ & -71.490 & -0.006 & 0.068 \\
\hline PPARGC1 (SNP2) & $\begin{array}{c}\mathrm{C} / \mathrm{T} \\
\text { c.3359 }\end{array}$ & -46.620 & -0.021 & -0.037 \\
\hline FSHR & $\begin{array}{c}\mathrm{A} / \mathrm{T} \\
\text { c. } 320\end{array}$ & -201.414 & $-0,010$ & -0.097 \\
\hline
\end{tabular}

BGH: Bovine growth hormone, PRL: Prolactin, IGF2a: Insulin-like growth factor 2a, POU1F1: Pituitary-specific transcription factor, INHA: Inhibin, LEP: Leptin. KC: Kappa-Casein, PPARGC1: Peroxisome proliferator activator receptor gamma coactivator $1 \alpha$, FSHR: follicle-stimulating hormone receptor. Substitution: allelic change and polymorphic site within the gene. 
This explains the differences in the effects of the M-BLUP model on the heritability of the three traits since the greatest effect was found for milk production and the smallest effect was found for SCS. As different authors have reported, there are QTLs with important effects for some traits, with a large participation in the variation, while having little or no effect on other traits (Lipkin et al., 2008b). This means that the variance explained by the QTL can represent a higher or lower proportion of the genetic variance in different traits and different populations (Szyda, Liu, Reinhardt, \& Reents, 2005). This determines the efficiency of the marker-assisted selection, which is greater when these QTLs can be fully identified thanks to their influence on the variation of the trait (Druet, Boichard, \& Colleau, 2006). Likewise, in a marker-assisted selection scheme in France, it was found that the QTL explained a greater proportion of the genetic variance for MP than for PP and that the gains obtained with the use of selection programs that include genetic information depend on the proportion of genetic variance explained by the QTL (Guillaume, Fritz, Boichard, \& Druet, 2008b).

From this, it was possible to generate estimated breeding values by animal model (EBV), marker-assisted selection model (MEBV), and breeding value at 305 days by random regression (EBV305), differentiating between those individuals for whom phenotypic and genetic information was available (that is, cows) and those individuals evaluated only based on their descendants (that is, bulls) (Table 7). In the case of cows, for MP, EBV and EBV305 allowed us to estimate higher breeding values with respect to those estimated by MEBV, while for PP and SCS, MEBV presented higher values on average with respect to EBV and EBV305. This was because there were more polymorphisms with a negative effect on the breeding value for MP than for PP and SCS (Table 6).

\section{Table 7}

Mean breeding value (EBV), molecular breeding value (MEBV) and 305-day breeding value by random regression model (EBV305) for milk production (MP), protein percentage (PP), and somatic cell score (SCS) estimated in Holstein cattle from Antioquia

\begin{tabular}{ccccccc|}
\multirow{2}{*}{ Trait } & \multicolumn{3}{c}{ Cows } & \multicolumn{3}{c|}{ Bulls } \\
\cline { 2 - 6 } & EBV & MEBV & EBV $_{305}$ & EBV & MEBV & EBV $_{305}$ \\
\hline MP (L) & -7.950 & -169.120 & 5.300 & 262.480 & -9.140 & -1.681 \\
PP (\%) & 0.001 & 0.018 & -0.0011 & 0.046 & -0.001 & -0.001 \\
SCS & -0.004 & 0.002 & -0.00034 & 0.215 & -0.001 & -0.001
\end{tabular}

In the case of bulls, the estimation of the different breeding values for PP and SCS showed little variation. Unlike what was observed for MP, since it had the change of greater dimension, but contrary to what was observed in cows, the mean of the MEBV for bulls was closer to zero, considering that there was no genotype information for any of the studs, it can be suggested that EBV is inferior because it agglomerates the effects of all the genes influencing the traits, including the genes used in the MBLUP model, whose polymorphisms had a negative effect. 
Table 8 contains the correlation coefficients between the genetic value at 305 days for the three traits under study and the three random regression coefficients used for modeling the additive genetic effect. The a0 coefficient had an approximate correlation of one with the genetic value at 305 days for the three traits; that is, the magnitude and direction of this coefficient determines the genetic value of each animal, so its reliability was used as reliability of the genetic value at 305 days. This agrees with reports where the first coefficient of the Legendre polynomial for the additive genetic effect has been associated with total milk production (Strabel \& Jamrozik, 2006), with similar behavior in this case for the protein percentage and somatic cell score.
In this sense, Table 9 shows the reliability of the estimated breeding value using a traditional animal model $\left(\left(r^{2}\right)\right.$ EBV), molecular breeding value $\left(\left(r^{2}\right) \mathrm{MEBV}\right)$ and 305-day breeding value by a random regression model ( $\left(r^{2}\right)$ EBV305) obtained for bulls and cows. Thanks to the use of the M-BLUP model, a significant increase in the reliability of breeding value was obtained for the three traits, with milk production being the trait that presented the greatest gain in reliability. The increase in reliability of breeding value is based on the greater additive genetic variance estimated by the model including molecular information, since this directly influences the reliability of the breeding value (Boligon et al., 2011). The above is consistent with reports that show an increase in the reliability of breeding value as one of the main advantages of molecular marker-assisted selection (Guillaume et al., 2008a).

Table 8

Correlation coefficients between the genetic value at 305 days for milk production (EBV ${ }_{305} M P$ ), protein percentage $\left(\mathrm{EBV}_{305} \mathrm{PP}\right)$ and somatic cell score $\left(\mathrm{EBV}_{305} \mathrm{SCS}\right)$ and three random regression coefficients $\left(a_{0^{\prime}} a_{1}, a_{2}\right)$ used for modeling the additive genetic effect in Holstein cattle from Antioquia

\begin{tabular}{|cccc|}
\hline & $a_{0}$ & $a_{1}$ & $a_{2}$ \\
\hline $\mathrm{EBV}_{305} \mathrm{PL}$ & 0.999 & 0.198 & 0.121 \\
\hline $\mathrm{EBV}_{305} \mathrm{PP}$ & 0.999 & 0.913 & -0.322 \\
\hline $\mathrm{EBV}_{305} \mathrm{SCS}$ & 1 & -0.995 & -0.943 \\
\hline
\end{tabular}

Table 9

Mean, standard deviation (SD), minimum value and maximum value for reliability of estimated breeding value (( $\left.r^{2}\right)$ EBV), molecular estimated breeding value $\left(\left(r^{2}\right)\right.$ MEBV) and breeding value at 305 days by random regression model ((r2) EBV305) for milk production (MP), protein percentage (PP), and somatic cell score (SCS) estimated in Holstein cattle from the department of Antioquia

\begin{tabular}{|c|c|c|c|c|c|c|c|c|c|c|c|c|}
\hline \multirow{3}{*}{ Trait } & \multicolumn{6}{|c|}{ Cows } & \multicolumn{6}{|c|}{ Bulls } \\
\hline & \multicolumn{2}{|c|}{$\left(r^{2}\right)$ EBV } & \multicolumn{2}{|c|}{$\left(r^{2}\right)$ MEBV } & \multicolumn{2}{|c|}{$\left(r^{2}\right)$ EBV305 } & \multicolumn{2}{|c|}{$\left(r^{2}\right)$ EBV } & \multicolumn{2}{|c|}{$\left(r^{2}\right)$ MEBV } & \multicolumn{2}{|c|}{$\left(r^{2}\right)$ EBV305 } \\
\hline & Mean & SD & Mean & SD & Mean & SD & Mean & SD & Mean & SD & Mean & $\mathrm{SD}$ \\
\hline MP & $37 \%^{b}$ & $130 \%$ & $57 \%{ }^{a}$ & $6 \%$ & $32 \% c$ & $8 \%$ & $55 \%{ }^{b}$ & $7 \%$ & $66 \%$ a & $4 \%$ & $23 \%^{c}$ & $9 \%$ \\
\hline PP & $43 \%^{b}$ & $130 \%$ & $57 \%^{a}$ & $9 \%$ & $61 \%{ }^{c}$ & $15 \%$ & $63 \%{ }^{b}$ & $12 \%$ & $70 \%{ }^{a}$ & $8 \%$ & $43 \%{ }^{b}$ & $13 \%$ \\
\hline SCS & $38 \%{ }^{b}$ & $130 \%$ & $42 \%{ }^{a}$ & $10 \%$ & $40 \%{ }^{c}$ & $11 \%$ & $54 \%{ }^{b}$ & $10 \%$ & $56 \%$ a & $9 \%$ & $29 \%^{c}$ & $10 \%$ \\
\hline
\end{tabular}

Letters in superscripts denote significant differences. 
It has been pointed out that one of the main advantages attributed to the random regression models compared to the traditional linear models is the possible reliability of the genetic value, since the control day models can better model the environmental effects and impact the genetic value of cows even more than bulls (Lidauer, Mäntysaari, \& Strandén, 2003). Although this difference in the reliability of the genetic value of cows and bulls could be corroborated in this study under the random regression model, it did not represent an advantage over the MBLUP model as a consequence of the lower heritability and genetic variance values found for the RRM, which condition the lower reliability of the genetic value. A difference in the reliability of the breeding value that favors the MBLUP model compared to the BLUP and RRM is presented despite the nullity of genotypes available for bulls and the lower of availability of genotyped cows for some of the markers relative to other reports, since the marker with the most genotypes available was the polymorphism of the BGH gene with 1126 individuals. The need to increase the number of genotyped individuals in order to increase the gains obtained through the use of MAS has been noted; by 2004, the French program for marker-assisted selection included 34,318 animals, of which 23,137 had phenotypic information and 16,629 had been genotyped for 43 microsatellites (Guillaume et al., 2008a), while in Germany, the use of 4500 genotypes for animals born between 1985 and 2000 was reported, with a complete pedigree of 7841 animals (Szyda et al., 2005). This highlights the importance of continuing to increase the amount of genetic information available for the animals to be evaluated.
Spearman's correlations between BLUP and M-BLUP were high, indicating great similarity in the ranking of individuals to be selected by both models. However, the correlation between RRM and the other two methodologies was not relevant, since all were close to zero, indicating that the animals to be selected under the RRM would be different than those selected under the other two models (Table 10). The Spearman correlation between BLUP and MBLUP was the lowest for MP of the three traits, both in bulls and in cows, because the greater influence of markers on this trait generated a greater change in the MEBV. As no genetic information was available for the bulls, their molecular breeding value was dependent on the performance of their daughters. The correlations between RRM and BLUP and MBLUP were not relevant since they were all close to 0 . This indicates that the animals to be selected under the RRM will be different than those selected under the other two models. This can be explained by the lower availability of individuals in the analysis when the RRM was used compared to the other methodologies, which can lead to relevant differences in the pedigree used in the RRM. There are also differences when genetic evaluation is carried out for total milk production and when productive controls are analyzed, since in the latter case, it is possible to accept differences at different points on the curve, whereas these differences are ignored by the models using total production; therefore, the adjustment of the genetic value for the accumulated production is different. 
Table 10

Spearman correlations between the genetic values estimated by random regression models (RRM) and by traditional animal models without (BLUP) or with molecular markers (MBLUP) in bulls and cows for three traits of economic importance in Holstein cattle from Antioquia

\begin{tabular}{ccccccc}
\hline \multirow{2}{*}{ Trait } & \multicolumn{3}{c}{ Cows } & \multicolumn{3}{c}{ Bulls } \\
\cline { 2 - 6 } & BLUP-MBLUP & RRM-BLUP & RRM-MBLUP & BLUP-MBLUP & RRM-BLUP & RRM-MBLUP \\
$\begin{array}{c}\text { Milk } \\
\text { production }\end{array}$ & 0.910 & 0.004 & 0.018 & 0.960 & 0.070 & 0.058 \\
$\begin{array}{c}\text { Protein } \\
\text { percentage }\end{array}$ & 0.950 & -0.008 & 0.009 & 0.990 & -0.009 & -0.007 \\
$\begin{array}{c}\text { Somatic cell } \\
\text { score }\end{array}$ & 0.930 & -0.009 & -0.011 & 0.990 & 0.018 & 0.022
\end{tabular}

\section{Conclusion}

The MBLUP model for marker-assisted selection led to estimates of greater genetic variance along with greater heritability, which produced a more reliable molecular breeding value than other methodologies. The molecular markers under study had different effects on the different traits of interest, affecting milk production to a greater extent than the other traits. Therefore, it is important to continue the research to identify molecular markers associated with each trait of interest and to evaluate their effects on components of variance and genetic parameters of each particular trait, since this will determine the genetic gains that can be achieved with MAS. Given that the random regression models presented lower heritability and less accurate genetic values compared to the BLUP and MBLUP models for both bulls and cows, the efficient use of these models requires the development of stable programs of traceability and animal registration, which allow increased productivity and kinship information.

\section{Funding}

This research was supported by the BIOGEM research group of the Department of Animal Production of Universidad Nacional de Colombia at Medellín and by the GaMMA research group of the Faculty of Agricultural Sciences of Universidad de Antioquia through the project "Strengthening the Northern Milk District of Antioquia".

\section{Conflict of interest}

The authors declare that they have no conflicts of interest.

\section{Acknowledgments}

The authors are grateful to the entire academic and research team of the BIOGEM and GaMMA research groups. 


\section{References}

Barbosa, P. F., Cruz, G. M. D., Costa, J. L. D., \& Rodrigues, A. D. A. (1999). Causas de variação da produção de leite em um rebanho da raça holandesa em São Carlos, SP. Revista Brasileira de Zootecnia, 28(5), 974-981. doi: 10.1590/S1516-3598 1999000500010

Bignardi, A.B., ElFaro, L., Torres, R.A., Jr., Cardoso, V. L., Machado, P. F., \& Albuquerque, L. G. (2011). Random regression models using different functions to model test-day milk yield of Brazilian Holstein cows. Genetics and Molecular Research, 10(4), 35653575. doi: 10.4238/2011.October.31.4

Boligon, A. A., Baldi, F., Mercadante, M. E., Lôbo, R. B., Pereira, R. J., \& Albuquerque, L. G. (2011). Breeding value accuracy estimates for growth traits using random regression and multi-trait models in Nelore cattle. Genetics and Molecular Research, 10(2), 1227-1236. doi: 10.4238/vol10-2gmr1087

Caccamo, M., Veerkamp, R. F., De Jong, G., Pool, M. H., Petriglieri, R., \& Licitra, G. (2008). Variance components for test-day milk, fat, and protein yield, and somatic cell score for analyzing management information. Journal of Dairy Science, 91(8), 3268-3276. doi: 10.3168/jds.20070805

Costa, C. N., Santos, G. G., Cobuci, J. A., Thompson, G., \& Carvalheira, J. G. (2015). Genetic parameters for test day somatic cell score in Brazilian Holstein cattle. Genetics and Molecular Research, 14(4), 19117-19127. doi: 10.4238/2015

De Roos, A. P., Harbers, A. G., \& De Jong, G. (2004). Random herd curves in a test-day model for milk, fat, and protein production of dairy cattle in the Netherlands. Journal of Dairy Science, 87(8), 2693-2701. doi: 10.3168/jds.S0022-0302(04)73396-2

Dornelles, M. D., Rorato, P. R. N., Gama, L. T., Breda, F. C., Bondan, C., Everling, D. M., \& Feltes, G. L. (2016). Random regression models using different functions to estimate genetic parameters for milk production in Holstein Friesians. Ciência Rural, 46(9), 1649-1655. doi: 10.1590/0103-8478cr20150473

Druet, T., Fritz, S., Boichard, D., \& Colleau, J. J. (2006). Estimation of genetic parameters for quantitative trait loci for dairy traits in the French Holstein population. Journal of Dairy Science, 89(10), 4070-4076. doi: 10.3168/jds.S0022-0302(06)72451-1

Gebreyesus, G., Lund, M. S., Janss, L., Poulsen, N. A., Larsen, L. B., Bovenhuis, H., \& Buitenhuis, A. J. (2016). Multi-trait estimation of genetic parameters for milk protein composition in the Danish Holstein. Journal of Dairy Science, 99(4), 2863-2866. doi: 10.3168/jds.2015-10501

González-Herrera, L. G. (2013). Parâmetros genéticos para produção de leite e persistência de lactações múltiplas na raça Gir. Tese de doutorado, Universidade Estadual Paulista, Faculdade de Ciências Agrárias e Veterinárias, Jaboticabal, SP, Brasil.

Guillaume, F., Fritz, S., Boichard, D., \& Druet, T. (2008a). Correlations of marker-assisted breeding values with progeny-test breeding values for eight hundred ninetynine French Holstein bulls. Journal of Dairy Science, 91(6), 2520-2522. doi: 10.3168/ jds.2007-0829 
Guillaume, F., Fritz, S., Boichard, D., \& Druet, T. (2008b). Estimation by simulation of the efficiency of the French marker-assisted selection program in dairy cattle. Genetics Selection Evolution, 40(1), 91-102. doi: 10.1051/gse:2007036

Haile-Mariam, M., Bowman, P. J., \& Goddard, M. E. (2003). Genetic and environmental relationship among calving interval, survival, persistency of milk yield and somatic cell count in dairy cattle. Livestock Production Science, 80(3), 189-200. doi: 10.1016/S0301-6226(02)00188-4

Hayes, B. (2007). QTL mapping, MAS, and genomic selection. Ames, lowa: Animal Breeding \& Genetics, Department of Animal Science, lowa State University. Retrieved from http://www.ans.iastate. edu/ section/abg/shortcourse/notes.pdf

Jakobsen, J. H., Madsen, P., Jensen, J., Pedersen, J., Christensen, L. G., \& Sorensen, D. A. (2002). Genetic parameters for milk production and persistency for Danish Holsteins estimated in random regression models using REML. Journal of Dairy Science, 85(6), 1607-1616. doi: 10.3168/jds.S0022-0302(02)74231-8

Jamrozik, J., Schaeffer, L. R., \& Dekkers, J. C. (1997). Genetic evaluation of dairy cattle using test day yields and random regression model. Journal of Dairy Science, 80(6), 1217-1226. doi: 10.3168/ jds.S0022-0302(97)76050-8

Khanzadeh, H., Hossein, N. G., \& Naserani, M. (2013). Estimation of genetic parameters and trends for milk fat and protein percentages in Iranian Holsteins using random regression test day model. Archives Animal Breeding, 56(47), 487496. doi: 10.7482/0003-9438-56-047
Kheirabadi, K., \& Alijani, S. (2014). Genetic parameters for milk production and persistency in the Iranian Holstein population by the multitrait random regression model. Archives Animal Breeding, 57(1), 1-12. doi: 10.7482/00039438-57-012

Lidauer, M., Mäntysaari, E. A., \& Strandén, I. (2003). Comparison of test-day models for genetic evaluation of production traits in dairy cattle. Livestock Production Science, 79(1), 73-86. doi: 10.1016/ S0301-6226(02)00142-2

Lipkin, E., Bagnato, A., \& Soller, M. (2008a). Expected effects on protein yield of marker-assisted selection at quantitative trait loci affecting milk yield and milk protein percentage. Journal of Dairy Science, 91(7), 2857-2863. doi: 10.3168/ jds.2008-1011

Lipkin, E., Tal-Stein, R., Friedmann, A., \& Soller, M. (2008b). Effect of quantitative trait loci for milk protein percentage on milk protein yield and milk yield in Israeli Holstein dairy cattle. Journal of Dairy Science, 91(4), 1614-1627. doi: 10.3168/jds.2007-0655

Liu, Z., Reinhardt, F., \& Reents, R. (2000). Parameter estimates of a random regression test day model for first three lactation somatic cell scores. Interbull Bulletin, 31(26), 61-65. Retrieved from https://journal. interbull.org/index.php/ib/ article/view/363

Makgahlela, M. L., Mäntysaari, E. A., Strandén, I., Koivula, M., Nielsen, U. S., Sillanpää, M. J., \& Juga, J. (2013). Across breed multi-trait random regression genomic predictions in the Nordic Red dairy cattle. Journal of Animal Breeding and Genetics, 130(1), 1019. doi: 10.1111/j.1439-0388.2012.01017.x 
Manoel, C., Melo, R., Packer, I. U., Costa, C. N., Machado, F., \& Patrício, M. (2007). Valores genéticos para as produções de leite do dia do controle e da lactação na raça Holandesa com diferentes modelos estatísticos. Brazilian Journal of Animal Science, 36(5), 1295-1303. doi: 10.1590/ S1516-3598200700 0600011

Meuwissen, T., Hayes, B., \& Goddard, M. (2013). Accelerating improvement of livestock with genomic selection. Annual Review of Animal Biosciences, 1(1), 221-237. doi: 10.1146/annurev-animal-031412-103705

Meyer, K. (2007). WOMBAT-A tool for mixed model analyses in quantitative genetics by restricted maximum likelihood (REML). Journal of Zhejiang University Science $B$, 8(11), 815-821. doi: 10.1631/jzus.2007. B0815

Mrode, R. (2005). Linear models for the prediction of animal breeding values (2nd ed.). Wallingford, UK: CABI publishing.

Mrode, R. A., \& Swanson, G. J. T. (2004). Calculating cow and daughter yield deviations and partitioning of genetic evaluations under a random regression model. Livestock Production Science, 86(1-3), 253-260. doi: 10.1016/j.livprodsci. 2003.09.001

Múnera, O. D., Herrera, A. C., González, L. G., Henao, A. F., \& Cerón, M. (2014). Variance and covariance components and genetic parameters for fat and protein yield of first-lactation holstein cows using random regression models. Revista Colombiana de Ciencias Pecuarias, 27(4), 253-263. Retrieved from http://www.scielo.org.co/scielo. php?script $=$ sci_arttext $\&$ pid $=$ S0120$06902014000400003 \&$ lng $=e n \&$ tlng $=e n$
Pereira, R. J., Verneque, R. S., Lopes, P. S., Santana, J. L., Lagrotta, M. R., Torres, R. A., Vercesi, A. E., F., \& Machado, M. A. (2012). Milk yield persistency in Brazilian Gyr cattle based on a random regression model. Genetics and Molecular Research, 11(2), 1599-1609. doi: 10.4238/2012

Rincón, F., Zambrano, A., \& Echeverri, J. (2015). Estimation of genetic and phenotypic parameters for production traits in Holstein and Jersey from Colombia. Revista MVZ Córdoba, 20(Supl)), 49624973. doi: 10.21897/rmvz.11

Ron, M., Feldmesser, E., Golik, M., Tager, I., Kliger, D., Reiss, V., \& Weller, J. I. (2004). A complete genome scan of the Israeli Holstein population for quantitative trait loci by a daughter design. Journal of Dairy Science, 87(2), 476-490. doi: 10.3168/jds. S0022-0302(04)73187-2

Schefers, J. M., \& Weigel, K. A. (2012). Genomic selection in dairy cattle: integration of DNA testing into breeding programs. Animal Frontiers, 2(1), 4-9. doi: 10.2527/ af.2011-0032

Solarte Portilla, C. E., \& Zambrano Burbano, G. L. (2012). Characterization and genetic evaluation of Holstein cattle in Nariño, Colombia. Revista Colombiana de Ciencias Pecuarias, 25(4), 539-547. Retrieved from https://www.redalyc.org/ articulo.oa?id=2950/295024922002

SAS/STAT ${ }^{\circledR}$. Copyright ${ }^{\oplus}$ 2003. Version 9.12003. (SAS Institute Incorporation: Cary, NC, USA). SAS and all other SAS Institute Inc. product or service names are registered trademarks or trademarks of SAS Institute Inc. in the USA and other countries. 
Strabel, T., \& Jamrozik, J. (2006). Genetic analysis of milk production traits of polish black and white cattle using large-scale random regression test-day models. Journal of Dairy Science, 89(8), 31523163. doi: 10.3168/jds.S0022-0302(06) 72589-9

Szyda, J., Liu, Z., Reinhardt, F., \& Reents, R. (2005). Estimation of quantitative trait loci parameters for milk production traits in German Holstein dairy cattle population. Journal of Dairy Science, 88(1), 356-367. doi: 10.3168/jds.S0022-0302(05)72695-3

Van Vleck, L. D., \& Boldman, K. G. (1993). Sequential transformation for multiple traits for estimation of (co)variance components with a derivative-free algorithm for restricted maximum likelihood. Journal of AnimalScience, 71(4), 836-844. doi:10.2527/1993.714836x

Wakchaure, R., Ganguly, S., Praveen, P. K., Kumar, A., Sharma, S., \& Mahajan, T. (2015). Marker assisted selection (MAS) in animal breeding: a review. Drug Metabolism and Toxicology, 6(5), 127. doi: 10.4172/21577609.1000 e127

Wiggans, G. R., \& Shook, G. E. (1987). A lactation measure of somatic cell count. Journal of Dairy Science, 70(12), 2666-2672. doi: 10.3168/jds.S0022-0302(87)80337-5
Yamazaki, T., Hagiya, K., Takeda, H., Sasaki, O., Yamaguchi, S., Sogabe, M., \& Nagamine, Y. (2013). Genetic correlations between milk production traits and somatic cell scores on test day within and across first and second lactations in Holstein cows. Livestock Science, 152(2-3), 120-126. doi: 10.1016/j.livsci.2012.12.015

Zambrano, J. C., Rincón, J. C., \& Echeverri, J. J. (2014). Parámetros genéticos para caracteres productivos y reproductivos en Holstein y Jersey colombiano. Archivos de Zootecnia, 63(243), 495-506. doi: $10.4321 / S 0004-05922014000300010$

Zhao, F. P., Guo, G., Wang, Y. C., Guo, X. Y., Zhang, Y., \& Du, L. X. (2015). Genetic parameters for somatic cell score and production traits in the first three lactations of Chinese Holstein cows. Journal of Integrative Agriculture, 14(1), 125-130. doi: 10.1016/ S2095-3119(14)60758-9

Zink, V., Lassen, J., \& Štipkova, M. (2012). Genetic parameters for female fertility and milk production traits in first-parity Czech Holstein cows. Czech Journal of Animal Science, 57(3), 108-114. doi: 10. 17221/5562-CJAS 
